\title{
Impact of Alternate Drought and Flooding Stress on Water Use, and Nitrogen and Phosphorus Losses in a Paddy Field
}

\author{
Mei Wang, Shuangen Yu*, Guangcheng Shao, Shikai Gao, Jiao Wang, Yidi Zhang \\ Key Laboratory of Efficient Irrigation-Drainage and Agricultural Soil-Water Environment in Southern China, \\ Ministry of Education, Nanjing, 210098, China \\ College of Water Conservancy and Hydropower Engineering, Hohai University, Nanjing 210098, China
}

Received: 12 April 2017

Accepted: 21 June 2017

\begin{abstract}
Alternate drought and flooding stress has become more prevalent during paddy growth stages as a result of climate change, especially in southern China. This study aims to assess the effect of alternate drought and flooding stress on water use, and nitrogen $(\mathrm{N})$ and phosphorus (P) losses in paddy fields. Two controlled irrigation and drainage (CID) managements (namely drought at the beginning of growth stages followed by flooding (CID-1), and flooding at the beginning of growth stages followed by drought (CID-2) and one alternated wetting and drying (AWD) management were designed in specially designed experimental tanks with three replications in 2015 and 2016. Results showed that CID increased effective irrigation quantities and rainwater storage ability with a significant decrease in water use efficiency compared with AWD. For surface water, CID-1 significantly improved possible losses of nitrogen and phosphorus during the fertilizer application period over CID-2. For subsurface water, CID can significantly reduce the leaching losses of nitrate N and P compared with AWD. Meanwhile, CID-1 significantly increased the leaching losses of nitrate $\mathrm{N}$ at the former two growth stages compared to CID-2, yet no significant difference was found for ammonia $\mathrm{N}$ and P. Therefore, the application of controlled irrigation and drainage - especially for CID-1 - was an efficient method for obtaining high water quality and reducing eutrophication.
\end{abstract}

Keywords: controlled irrigation and drainage, alternate wetting and drying, control drainage, paddy

\section{Introduction}

Paddy is the most important grain crop in China. In addition, water is one of the most important components for sustainable paddy production, and the quantity of

*e-mail: seyu@hhu.edu.cn irrigation for paddy fields accounts for approximately $70 \%$ of its total agricultural water resource consumption [1]. However, water supply is limited because of serious regional and seasonal water shortages, and paddy production is impaired by increasing water shortage [2]. Meanwhile, China is the largest producer and consumer of synthetic fertilizers in the world. Fertilizer and pesticide overuse in order to achieve high paddy yields might result not only in poor grain yield but also low $\mathrm{N}$ use 
efficiency, massive $\mathrm{N}$ losses, and environmental pollution [3-4]. Nitrogen and phosphorus losses are determined by the concentration and the runoff volume, yet when the amounts of $\mathrm{N}$ and $\mathrm{P}$ in topsoil are small, their losses mostly depend on the volume of runoff [5]. Moreover, irrational surface and subsurface drainage by farmers can enhance the loss of water, which leads to serious $\mathrm{N}$ and $\mathrm{P}$ losses [6]. Therefore, several water-saving irrigation technologies and control drainage practices have been developed to solve water shortage and water environment deterioration.

The most typical water-saving irrigation technology is alternate wetting and drying (AWD), in which paddy soil is treated with alternating periods of wet or dry and standing water [7-8]. AWD irrigation can reduce unproductive losses of water due to lower percolation and evaporation. Previous studies have shown that AWD can reduce the $\mathrm{N}$ and $\mathrm{P}$ leaching by significantly cutting the volume of percolating water compared with conventional flooding irrigation [9-10]. Controlled drainage can control the groundwater table effectively via the installation of a subsurface drain. This method is widely employed in northeastern Italy, southwestern Japan, and southern Sweden [11-13]. Controlled drainage not only can improve water use by regulating the water table reasonably, but it promotes the absorption and utilization of $\mathrm{N}$ and $\mathrm{P}$ by controlling the retention times of stormwater in fields and drains [14, 15]. $\mathrm{N}$ and $\mathrm{P}$ concentrations were not significantly different between controlled drainage and conventional drainage, whereas $\mathrm{N}$ and $\mathrm{P}$ losses tend to be lower due to lower runoff volumes in control drainage $[14,15]$.

Recently, researchers implemented controlled irrigation and drainage (CID), which takes advantage of both AWD and control drainage. It has been a focus of agricultural water conservation and environmental study [16-17]. Peng et al. demonstrated that control of groundwater depth not only can significantly promote the efficient use of water and change the water demand regulation, but also can control and reduce $\mathrm{N}$ and $\mathrm{P}$ losses in surface and underground drain discharge from paddy fields [18]. Xiao et al. found that prolonging flood times under CID can significantly reduce ammonia $\mathrm{N}\left(\mathrm{NH}_{4}^{+}-\mathrm{N}\right)$ and total $\mathrm{P}(\mathrm{TP})$ concentrations [19]. A field experiment conducted by Gheysari et al. showed that $\mathrm{N}$ uptake decreased and final soil $\mathrm{N}$ leaching increased for deficit irrigation management as compared to adequate irrigation management [20]. Most of the existing studies on water management in paddy fields are focused on the effect of single flooding or deficit water stress on $\mathrm{N}$ and $\mathrm{P}$ losses. Nevertheless, few studies have focused on the effect of alternate drought and flooding conditions on $\mathrm{N}$ and $\mathrm{P}$ losses and water systems. Under CID, paddy fields can store a higher water volume after a storm or irrigation and endure moisture deficit periods, which may form an alternate drought and flood conditions for plant growth. Alternate drought and flooding may become more prevalent at any paddy growth stage as a result of climate change, especially in southern China [21]. Paddy is a semi-aquatic plant, thus we can take full advantage of the stress of drought and waterlogging on paddy to control stress. We previously reported the potential of CID at the single growth stage for the changes of $\mathrm{N}$ and $\mathrm{P}$ concentrations from rice paddies in Southern China [22]. In that study, the effect of CID at continuous growth stages of paddy was not deeply investigated. Therefore, the present study was designed to further explore the effect of alternate drought and flooding stress on water use, and $\mathrm{N}$ and $\mathrm{P}$ losses under CID in paddy fields at continuous growth stages. This can provide a series of research technical indicators on CID in paddy fields not only for improving water quality and maintaining high yield, but also for achieving comprehensive benefits from environmental and economic resources. Our study hypothesizes that tanks have the same seepage and percolation rates when a water table exists at the soil surface, and water table recession occurs evenly when floodwater recedes.

\section{Materials and Methods}

\section{Experimental Site and the Soil Properties}

Experiments were implemented in experimental tanks at the Key Laboratory of Efficient Irrigation-Drainage and Agricultural Soil-Water Environment in Southern China, Ministry of Education $\left(31^{\circ} 57^{\prime} \mathrm{N}, 118^{\circ} 50^{\prime} \mathrm{E}\right.$, and $144 \mathrm{~m}$ above sea level), during the paddy growing season of 2015, and repeated in 2016. The study area has a subtropical humid monsoon climate with an average annual temperature of $15.4^{\circ} \mathrm{C}$, annual precipitation of $1,051 \mathrm{~mm}$, annual evaporation of $900 \mathrm{~mm}$, and a frostfree period of 220 days per year. The soil type of the experimental field is a typical permeable paddy soil formed on losses deposits with loamy clay. The soil $(0-30 \mathrm{~cm})$ in tanks with $\mathrm{pH}$ of 6.97 includes $2.19 \%$ of soil organic matter, $0.91 \mathrm{~g} / \mathrm{kg}$ of total nitrogen, $27.65 \mathrm{mg} / \mathrm{kg}$ of available nitrogen, $0.32 \mathrm{~g} / \mathrm{kg}$ of total phosphorus, and $12.5 \mathrm{mg} / \mathrm{kg}$ of available phosphorus. Nine fixed tanks $2 \mathrm{~m}$ wide, $2.5 \mathrm{~m}$ long, and $2 \mathrm{~m}$ high were needed, and the container was constructed from concrete block and sealed with waterproof paint. An integrated irrigation-drainage system was installed in the experimental field (Fig. 1). A mobile canopy is equipped on the ground, and remains closed during the rain period.

\section{Plant Material and Agricultural Activities}

Nangeng 9108 was used in the experimental tanks. For two years in a row, seedlings were raised in a seedbed on 13 May 2015 (15 May 2016) and then transplanted on 16 June 2015 (24 June 2016) at a hill spacing of $0.2 \mathrm{~m} \times 0.14 \mathrm{~m}$, with three seedlings per hill. The soil was soaked the day before transplanting and then flooded for about a week with a 20-30 mm water layer to promote good crop establishment. Weeds were controlled manually and pesticides were applied 


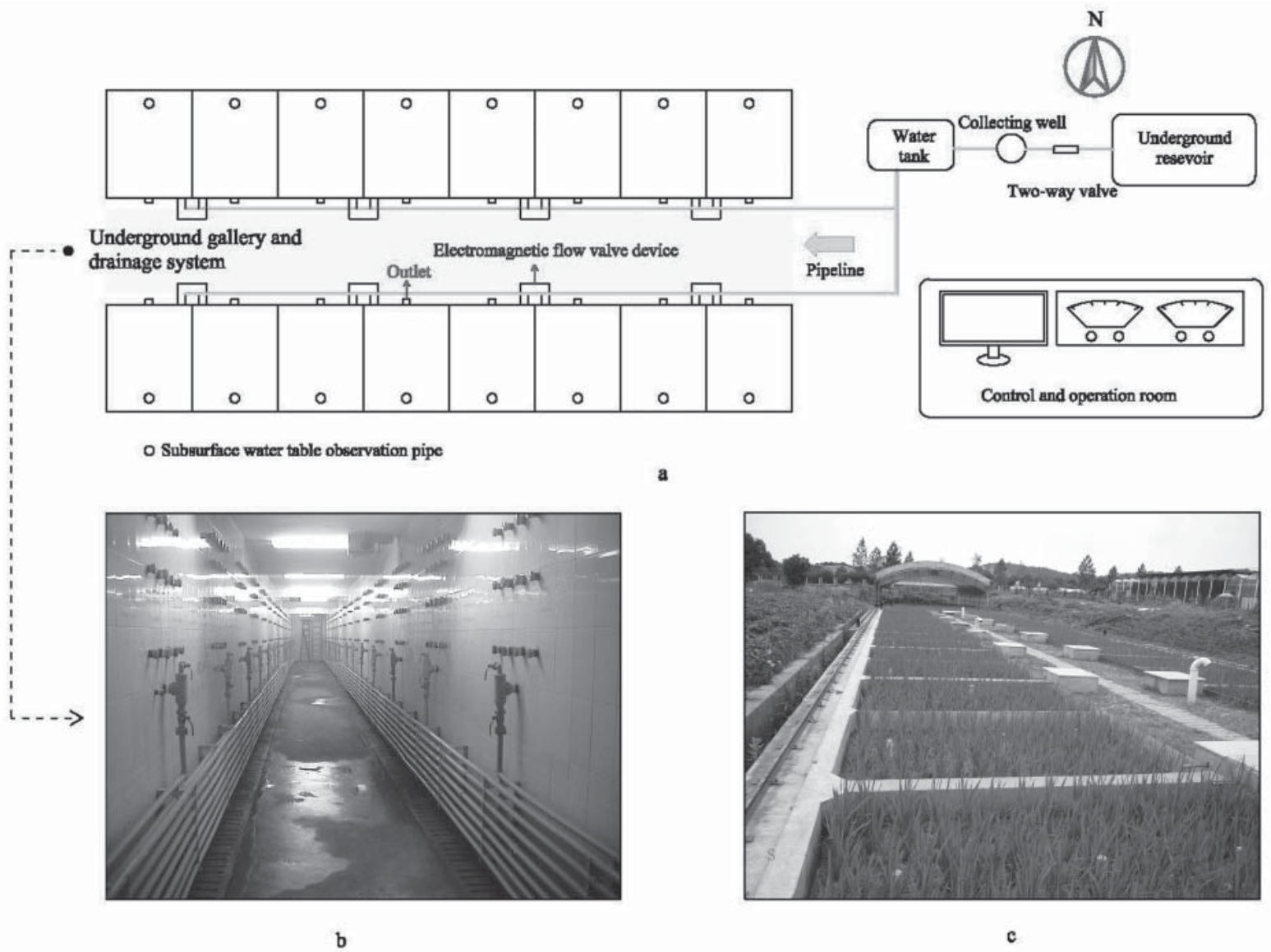

Fig. 1. a) Layout of the study area and experimental management. Water was supplied from an underground reservoir to every fixed tank plot through pipelines. b) Picture of underground gallery and drainage system. (c) Picture of fixed tank plot.

occasionally. The fertilizer activities used in this experiment were described in Table 1.

\section{Experimental Designs}

We designed two controlled irrigation and drainage management systems: drought at the beginning of growth followed by flooding (CID-1), and flooding at the beginning of growth followed by drought (CID2). Conventional AWD management was designed $f$ or comparison. All treatments were set up in the experimental tanks with closed bottoms and kept to three replications. For the first 10 days after transplanting, shallow water $(10-40 \mathrm{~mm})$ was kept in both water regimes to facilitate seedling recovery and turning green.
Hereafter the CID and AWD were managed differently, as shown in Table 2.

\section{Sample Collection and Measurement}

In this study we calculated the seasonal water use of paddy by the water balance principle as follows:

$$
E T_{\mathrm{t}}=P_{t}+I_{t}-W_{t-1}+W_{t}-D_{t}
$$

...where ET is evapotranspiration ( $\mathrm{mm}) ; P$ is precipitation $(\mathrm{mm})$, recorded daily by an automatic weather station (ICT, Australia); I is irrigation water $(\mathrm{mm})$, recorded by the integrated irrigation systems; $W$ is water depth (measured by vertical rulers every morning at 09:00)

Table 1. Date of fertilizer activities during the rice growing season.

\begin{tabular}{|c|c|c|c|}
\hline \multirow{2}{*}{ Activities } & Remarks & \multicolumn{2}{|c|}{ Date } \\
\cline { 2 - 4 } & & 2015 & 2016 \\
\hline Base fertilizer & Compound fertilizer $\left(\mathrm{N}: \mathrm{P}_{2} \mathrm{O}_{5}: \mathrm{K}_{2} \mathrm{O}, 15: 15: 15,900 \mathrm{~kg} / \mathrm{ha}\right)$ & 13 June & $22 \mathrm{June}$ \\
\hline Tillering fertilizer & Urea (nitrogen content of $46.4 \%, 100 \mathrm{~kg} / \mathrm{ha})$ & $28 \mathrm{June}$ & $5 \mathrm{July}$ \\
\hline Panicle fertilizer & Urea (nitrogen content of $46.4 \%, 50 \mathrm{~kg} / \mathrm{ha})$ & 26 July & 3 August \\
\hline
\end{tabular}


Table 2. Design of controlled irrigation and drainage scheduling.

\begin{tabular}{|c|c|c|c|c|c|c|c|}
\hline \multirow{2}{*}{ Stages } & \multicolumn{3}{|c|}{ Water depth design (mm) } & \multicolumn{4}{c|}{ Period of water control (month/day) } \\
\cline { 2 - 8 } & CID-1 & CID-2 & AWD & \multicolumn{2}{|c|}{ CID-1 } & \multicolumn{2}{c|}{ CID-2 } \\
\cline { 5 - 8 } & & & 2015 & 2016 & 2015 & 2016 \\
\hline Tillering & $-500 \sim 150$ & $250 \sim-500$ & $\begin{array}{c}-200 \sim 30 \\
\sim 60\end{array}$ & $\begin{array}{c}\text { July 3-July } \\
\text { 8-July 13 }\end{array}$ & $\begin{array}{c}\text { July 14-July } \\
\text { 21-July 30 }\end{array}$ & $\begin{array}{c}\text { July 3-July } \\
\text { 7-July 14 }\end{array}$ & $\begin{array}{c}\text { July 7-July } \\
11-J u l y ~ 22\end{array}$ \\
\hline $\begin{array}{c}\text { Jointing- } \\
\text { booting }\end{array}$ & $-500 \sim 250$ & $250 \sim-500$ & $\begin{array}{c}-300 \sim 50 \\
\sim 100\end{array}$ & $\begin{array}{c}\text { July 29-Aug. } \\
\text { 3-Aug. 8 }\end{array}$ & $\begin{array}{c}\text { Aug. 7-Aug. } \\
\text { 10-Aug. 17 }\end{array}$ & $\begin{array}{c}\text { July 29-Aug. } \\
\text { 3-Aug. 9 }\end{array}$ & $\begin{array}{c}\text { Aug. 7-Aug. } \\
11-A u g . ~ 16\end{array}$ \\
\hline $\begin{array}{c}\text { Heading- } \\
\text { flowering }\end{array}$ & $-500 \sim 250$ & $250 \sim-500$ & $\begin{array}{c}-200 \sim 50 \\
\sim 150\end{array}$ & $\begin{array}{c}\text { Aug. 23-Aug. } \\
\text { 28-Sept. 1 }\end{array}$ & $\begin{array}{c}\text { Aug. 19-Aug. } \\
\text { 23-Sept. 2 }\end{array}$ & $\begin{array}{c}\text { Aug. 23-Aug. } \\
\text { 28-Sept. 4 }\end{array}$ & $\begin{array}{c}\text { Aug. 19-Aug. } \\
\text { 23-Aug. 28 }\end{array}$ \\
\hline Milky & $-500 \sim 250$ & $250 \sim-500$ & $\begin{array}{c}-200 \sim 50 \\
\sim 150\end{array}$ & $\begin{array}{c}\text { Sept. 13-Sept. } \\
\text { 18-Sept. 23 }\end{array}$ & $\begin{array}{c}\text { Sept. 10-Sept. } \\
\text { 15-Sept. 23 }\end{array}$ & $\begin{array}{c}\text { Sept. 12-Sept. } \\
\text { 17-Sept. 23 }\end{array}$ & $\begin{array}{c}\text { Sept. 10-Sept. } \\
\text { 14-Sept. 23 }\end{array}$ \\
\hline
\end{tabular}

Note: $-\mathrm{I} \sim \mathrm{J} \sim \mathrm{K}$ denotes that water depth was kept between $-\mathrm{I} \mathrm{mm}$ and $\mathrm{J} \mathrm{mm}$ at four stages of paddy fields at normal time; the maximum storage water depth after rain was kept at $\mathrm{K} \mathrm{mm} ;-\mathrm{H} \sim \mathrm{L}$ indicates that at the beginning of growth period water was consumed naturally to the lower limit value of $\mathrm{H}$, then irrigated water to the upper limit value of $\mathrm{L}$ and kept at natural consumption; $\mathrm{L} \sim-\mathrm{H}$ indicates that at the beginning of growth period the upper limit vale $\mathrm{L}$ was obtained, then drained to no water lever and naturally consumed to the lower limit value $\mathrm{H}$; the rest of growth days for CID were performed according to the requirement of AWD; the middle value of growth period indicates the day of drought turned to flooding or flooding drain to no water level.
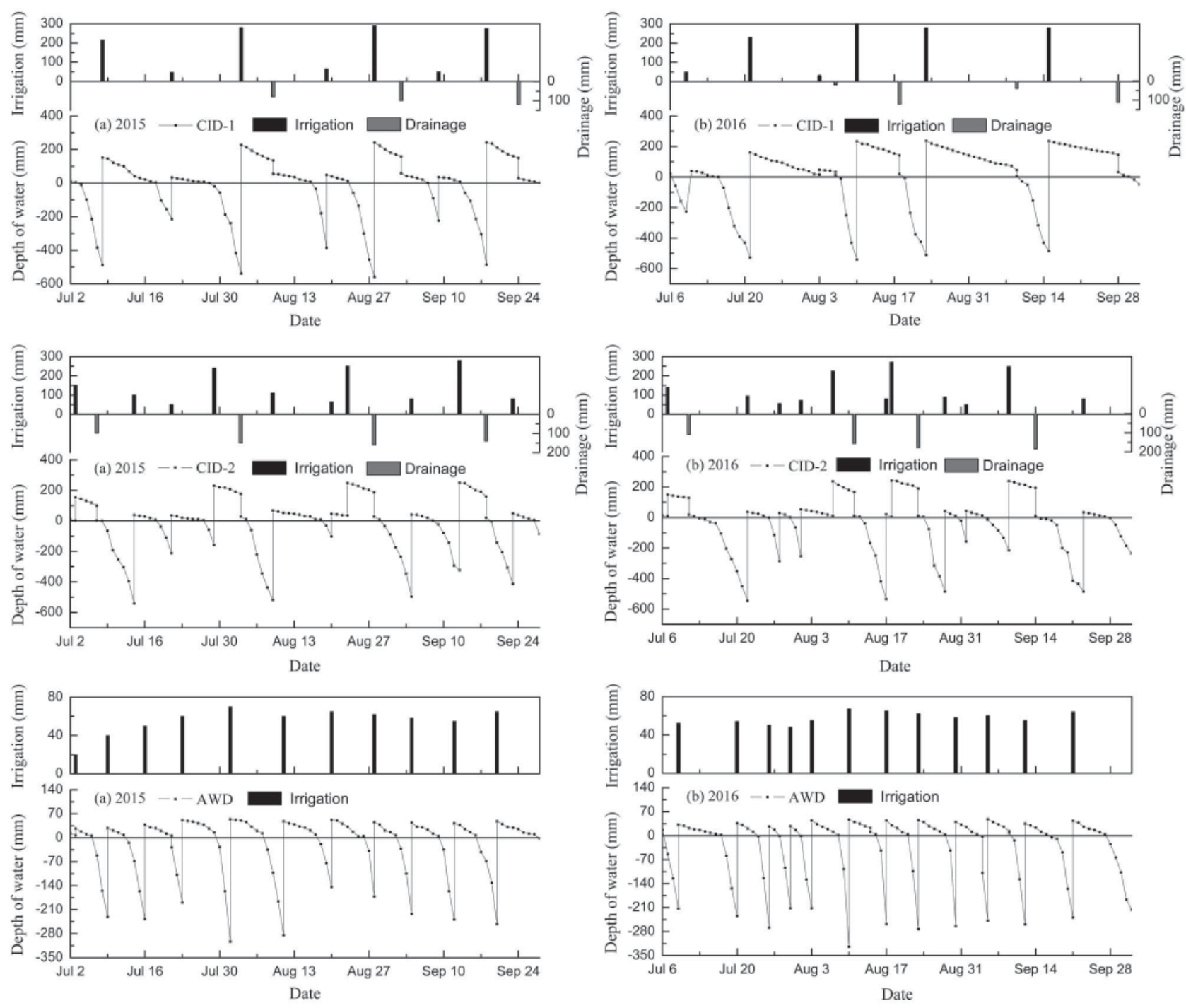

Fig. 2. Typical irrigation, drainage, and water table depth of CID and AWD in 2015 a) and 2016 b). 
or the soil water content in the root zone $(\mathrm{mm}) ; D$ is the volume of drainage and underlying root leakage $(\mathrm{mm})$; and $t$ is the day of determination. A $2 \mathrm{~mm}$ water leak per day was allowed when the paddy soil existed at water level.

Water samples were collected in polyethylene bottles three times during the water control period. The surface water was collected using $50 \mathrm{~mL}$ syringes (without
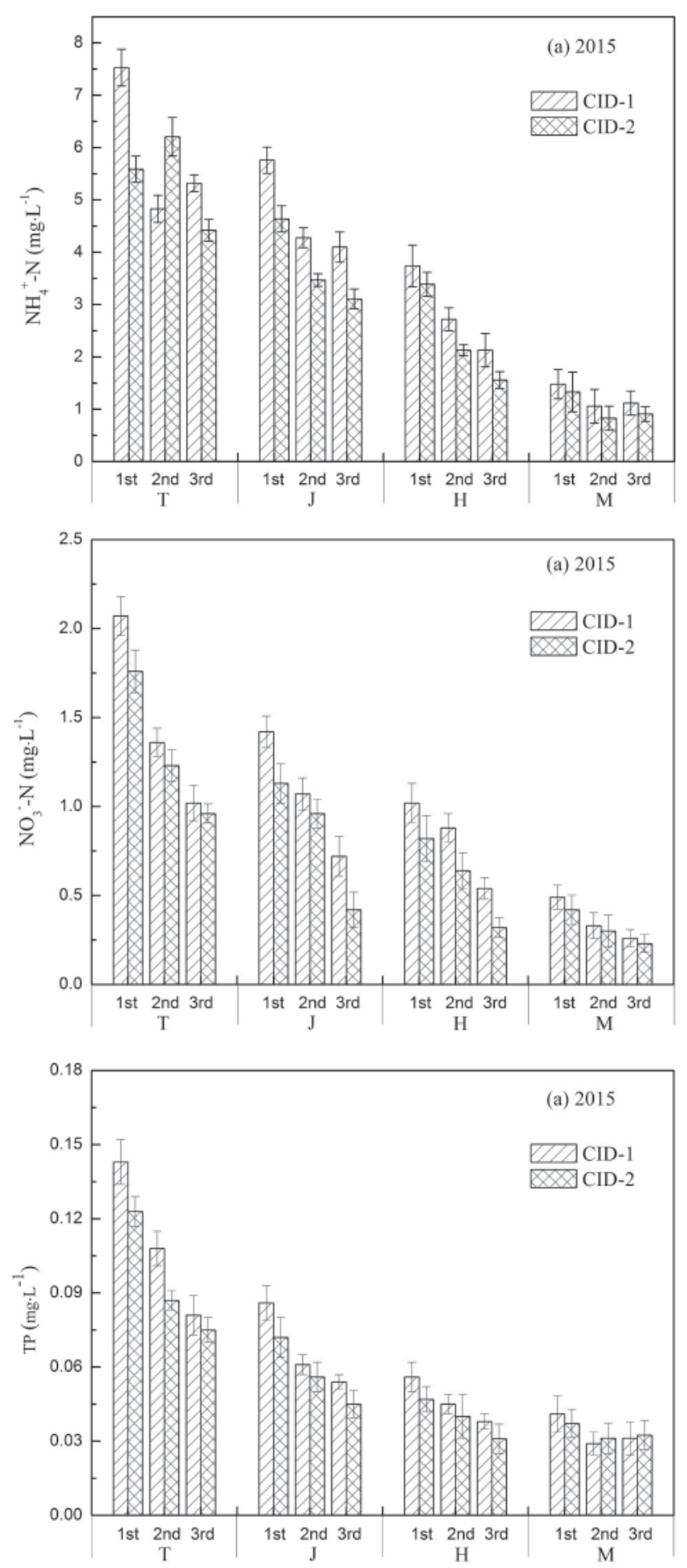

disturbing the soil and selecting the top surface water randomly); the subsurface water was collected from an underground drainage pipe; all bottoms were rinsed before an appropriate amount of water sample was obtained. Water collection times are shown in Figs 3-4. Ammonia nitrogen $\left(\mathrm{NH}_{4}^{+}-\mathrm{N}\right)$, nitrate nitrogen $\left(\mathrm{NO}_{3}^{-}-\mathrm{N}\right)$, and total phosphorus (TP) in the water were analyzed by the indophenol blue, disulfonic acid phenol, and
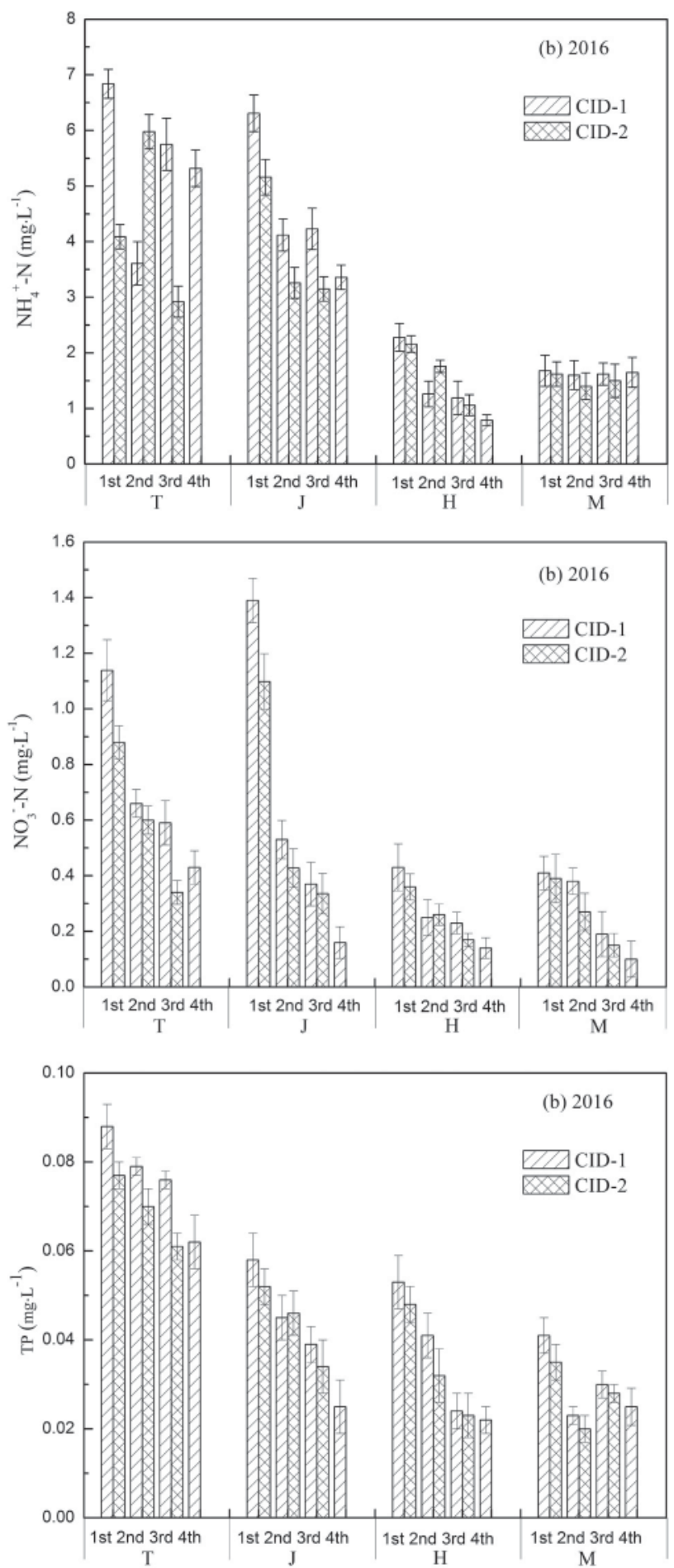

Fig. 3. Changes of $\mathrm{NH}_{4}^{+}-\mathrm{N}, \mathrm{NO}_{3}^{-}-\mathrm{N}$, and TP concentrations in surface water under CID in 2015 a) and $2016 \mathrm{~b}$ ). $1^{\text {st }}, 2^{\text {nd }}$, and $3^{\text {rd }}$ means the concentration on the first, third, and fifth day of flooding. $4^{\text {th }}$ means the concentration in the end of flooding control for CID- 1 treatment. $\mathrm{T}, \mathrm{J}, \mathrm{H}$, and $\mathrm{M}$ represent tillering stage, jointing-booting stage, heading-flowering stage, and milky stage, respectively. 

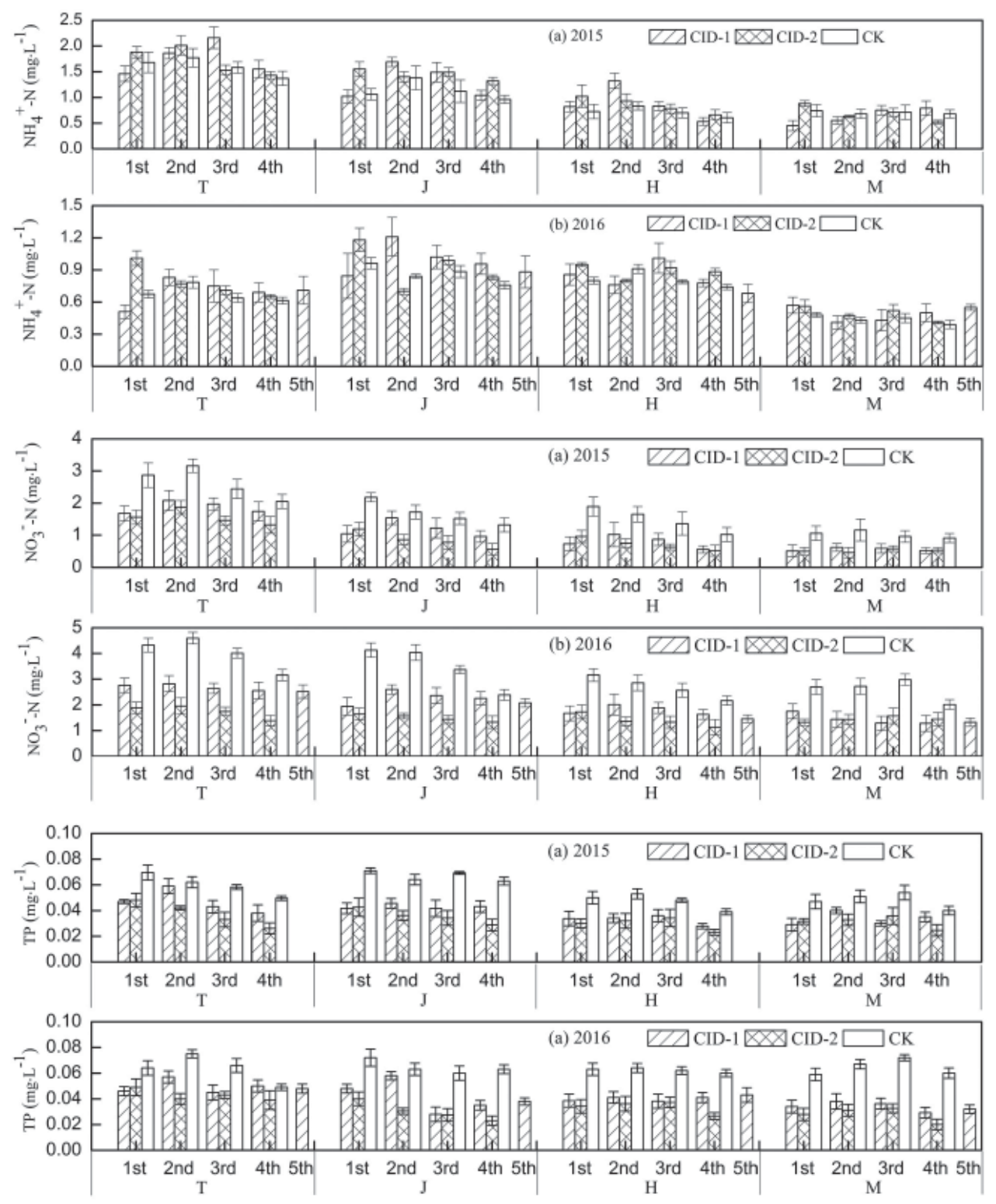

Fig. 4. Changes of $\mathrm{NH}_{4}^{+}-\mathrm{N}, \mathrm{NO}_{3}^{-}-\mathrm{N}$, and TP concentrations in subsurface water under CID and AWD in 2015 a) and 2016 b). For CID-1, $1^{\text {st }}$ and $5^{\text {th }}$ means concentration in the end of drought and flooding day, and $2^{\text {nd }}, 3^{\text {rd }}$, and $4^{\text {th }}$ means concentration on the first, third, and fifth day of flooding. For CID-2, $1^{\text {st }}, 2^{\text {nd }}$, and $3^{\text {rd }}$ means concentration on the first, third, and fifth day of flooding, and 4th means concentration in the end of drought. For AWD, $1^{\text {st }}, 2^{\text {nd }}, 3^{\text {rd }}$, and 4 th means concentration at once every other day during one wetting and drying cycle. $T$, $\mathrm{J}, \mathrm{H}$, and $\mathrm{M}$ represent tillering stage, jointing-booting stage, heading-flowering stage, and milky stage, respectively.

ammonium molybdate spectrophotometric methods using a Shimadzu UV-2800 spectrophotometer. The possible losses from surface water were calculated by multiplying the concentration and the excessive allowable water depth. The losses via subsurface water were calculated by multiplying the water leakage volume between the two dates and the concentration in the sample taken on a later day.

\section{Statistical Analysis}

Statistical analysis was carried out using the standard procedures on a randomized plot design (SPSS 19.0). The method of t-text was used to evaluate the difference of measured variables at the 0.05 probability level. Significance was calculated based on least significance (LSD) test at the 0.05 probability level. The chart in this study was drawn using the software of origin 8.0.

\section{Results}

\section{Water Table Depth and Paddy Yields}

Water table depth fluctuations, typical irrigation volumes, and drainage volumes of treatments in 2015 and 2016 are shown in Fig. 2. Irrigation and drainage events caused the tank water depth to rise or drop. Duration 
Table 3. Evapotranspiration (ET), paddy fields, and water use efficiency (WUE) for CID-1, CID-2, and AWD.

\begin{tabular}{|c|c|c|c|c|c|c|}
\hline \multirow{2}{*}{ Treatment } & \multicolumn{3}{|c|}{2015} & \multicolumn{2}{c|}{2016} \\
\cline { 2 - 7 } & ET $(\mathrm{mm})$ & Yields $\left(\mathrm{kg} \mathrm{ha}^{-1}\right)$ & WUE $\left(\mathrm{kg} \mathrm{m}^{-3}\right)$ & ET $(\mathrm{mm})$ & Yields $\left(\mathrm{kg} \mathrm{ha}^{-1}\right)$ & WUE $\left(\mathrm{kg} \mathrm{m}^{-3}\right)$ \\
\hline CID-1 & $631^{\mathrm{a}}$ & $6954^{\mathrm{c}}$ & $1.12^{\mathrm{c}}$ & $644^{\mathrm{a}}$ & $6678^{\mathrm{c}}$ & $1.04^{\mathrm{b}}$ \\
\hline CID-2 & $539^{\mathrm{a}}$ & $7680^{\mathrm{b}}$ & $1.42^{\mathrm{b}}$ & $584^{\mathrm{a}}$ & $7246^{\mathrm{b}}$ & $1.24^{\mathrm{b}}$ \\
\hline AWD & $493^{\mathrm{a}}$ & $8310^{\mathrm{a}}$ & $1.68^{\mathrm{a}}$ & $540^{\mathrm{a}}$ & $8126^{\mathrm{a}}$ & $1.50^{\mathrm{a}}$ \\
\hline
\end{tabular}

Note: Means followed by the same letter $(a, b, c)$ do not differ significantly at the $5 \%$ level by LSD.

without water level conditions for CID-1, CID-2, and AWD treatments was 26, 38, and 35 days in 2015 and 27, 45, and 40 days in 2016, respectively. Effective irrigation quantities (calculated by subtracting total drainage volumes from total irrigation volumes) for CID-1 and CID-2 were 1.54 and 1.40 times higher in 2015, and 1.30 and 1.13 times higher in 2016 than AWD, respectively. For CID-1 and CID-2, evapotranspiration (ET) was increased by $28.0 \%$ and $9.4 \%$ in 2015 , and $19.3 \%$ and $8.2 \%$ in 2016 compared to AWD, respectively. However, compared with AWD, the grain yields under CID-1 and CID-2 were decreased by $13.8 \%$ and $6.8 \%$ across two years, and water use efficiency (WUE) was significantly reduced by $36.4 \%$ and $13.9 \%$, respectively (Table 3 ).

\section{Nitrogen and Phosphorus Concentrations and Losses in Surface Water}

The changes of $\mathrm{NH}_{4}^{+}-\mathrm{N}, \quad \mathrm{NO}_{3}^{-}-\mathrm{N}$, and TP concentrations in the surface water of paddy fields under CID in 2015 (a) and 2016 (b) are shown in Fig. 3. During the four growth stages of water control, $\mathrm{NH}_{4}^{+}-\mathrm{N}$, $\mathrm{NO}_{3}^{-}-\mathrm{N}$, and TP concentrations under CID reached the peak in the first day of flooding and then dropped to stable values as flooding times went on, except that $\mathrm{NH}_{4}^{+}-\mathrm{N}$ concentration under CID-2 at the tillering stage obtained peak value in the third flooding day. $\mathrm{NH}_{4}^{+}-\mathrm{N}, \mathrm{NO}_{3}{ }^{-} \mathrm{N}$, and TP concentrations of CID-1 treatment in the first flooding day at four growth stages for CID-1 treatment were higher than of CID-2 treatment $(34.0 \%, 24.1 \%, 10.1 \%$, and $11.2 \%$ higher in 2015 , and $67.2 \%, 22.3 \%, 5.5 \%$, and $3.7 \%$ higher in 2016 for $\mathrm{NH}_{4}^{+}-\mathrm{N} ; 17.6 \%, 25.6 \%, 19.5 \%$, and $11.3 \%$ higher in 2015 , and $29.4 \%, 26.6 \%, 19.4 \%$, and $5.1 \%$ higher in 2016 for $\mathrm{NO}_{3}^{-}-\mathrm{N}$; and $16.3 \%, 19.4 \%, 19.1 \%$, and $10.2 \%$ higher in 2015 , and $14.2 \%, 11.5 \%, 10.4 \%$, and $11.4 \%$ higher in 2016 for TP). Possible losses of $\mathrm{NH}_{4}^{+}-\mathrm{N}$, $\mathrm{NO}_{3}^{-}-\mathrm{N}$, and TP on the fifth day of flooding for CID-1 treatment were higher than for CID-2 treatment at each growth stage in two years. However, for $\mathrm{NH}_{4}^{+}-\mathrm{N}$ and TP significant differences $(\mathrm{P}<0.05)$ only existed at the tillering and jointing-booting stages, yet for $\mathrm{NO}_{3}^{-}-\mathrm{N}$ significant differences were observed at the former three growth stages (Table 4).

\section{Nitrogen and Phosphorus Concentrations and Losses in Subsurface Water}

The changes of $\mathrm{NH}_{4}^{+}-\mathrm{N}, \mathrm{NO}_{3}^{-}-\mathrm{N}$, and $\mathrm{TP}$ concentrations in subsurface water under CID and AWD in 2015 (a) and 2016 (b) are shown in Fig. 4. For CID-1 treatment at each growth stage, $\mathrm{NH}_{4}^{+}-\mathrm{N}, \mathrm{NO}_{3}^{-}-\mathrm{N}$, and TP concentrations in the first flooding day showed higher values than at the end of drought control. Changes in $\mathrm{NH}_{4}^{+}-\mathrm{N}, \mathrm{NO}_{3}^{-}-\mathrm{N}$, and TP concentrations for CID-1 during the flooding period showed a decreased trend except for $\mathrm{NH}_{4}^{+}-\mathrm{N}$ concentrations at the milky stage, which presented an upward trend. The changes of $\mathrm{NH}_{4}^{+}-\mathrm{N}$, $\mathrm{NO}_{3}^{-}-\mathrm{N}$, and TP concentrations for CID-2 and AWD varied in similar patterns. During four growth stages of water control, $\mathrm{NH}_{4}^{+}-\mathrm{N}, \mathrm{NO}_{3}^{-}-\mathrm{N}$, and $\mathrm{TP}$ concentrations

Table 4. Nitrogen and phosphorus possible losses by surface drainage at the fifth flooding day during the four growth stages in 2015 and 2016.

\begin{tabular}{|c|c|c|c|c|c|c|c|c|c|}
\hline \multirow{2}{*}{ Form of N and P } & \multirow{2}{*}{ Treatments } & \multicolumn{4}{|c|}{2015} & \multicolumn{4}{|c|}{2016} \\
\cline { 3 - 10 } & $\mathrm{T}$ & $\mathrm{J}$ & $\mathrm{H}$ & $\mathrm{M}$ & $\mathrm{T}$ & $\mathrm{J}$ & $\mathrm{H}$ & $\mathrm{M}$ \\
\hline \multirow{2}{*}{$\begin{array}{c}\mathrm{NH}_{4}^{+}-\mathrm{N} \\
\left(\mathrm{g} \mathrm{ha}^{-1}\right)\end{array}$} & $\mathrm{CID}-1$ & $335^{\mathrm{a}}$ & $492^{\mathrm{a}}$ & $256^{\mathrm{a}}$ & $135^{\mathrm{a}}$ & $327^{\mathrm{a}}$ & $575^{\mathrm{a}}$ & $163^{\mathrm{a}}$ & $249^{\mathrm{a}}$ \\
\cline { 2 - 11 } & $\mathrm{CID}-2$ & $230^{\mathrm{b}}$ & $435^{\mathrm{b}}$ & $239^{\mathrm{a}}$ & $128^{\mathrm{a}}$ & $228^{\mathrm{b}}$ & $369^{\mathrm{b}}$ & $147^{\mathrm{a}}$ & $216^{\mathrm{a}}$ \\
\hline $\begin{array}{c}\mathrm{NO}_{3}^{-}-\mathrm{N} \\
\left(\mathrm{g} \mathrm{ha}^{-1}\right)\end{array}$ & $\mathrm{CID}-1$ & $64^{\mathrm{a}}$ & $80^{\mathrm{a}}$ & $55^{\mathrm{a}}$ & $31^{\mathrm{a}}$ & $34^{\mathrm{a}}$ & $51^{\mathrm{a}}$ & $30^{\mathrm{a}}$ & $29^{\mathrm{a}}$ \\
\cline { 2 - 11 } & $\mathrm{CID}-2$ & $50^{\mathrm{b}}$ & $59^{\mathrm{b}}$ & $43^{\mathrm{b}}$ & $32^{\mathrm{a}}$ & $27^{\mathrm{b}}$ & $39^{\mathrm{b}}$ & $21^{\mathrm{b}}$ & $27^{\mathrm{a}}$ \\
\hline $\begin{array}{c}\mathrm{TP} \\
\left(\mathrm{g} \mathrm{ha}^{-1}\right)\end{array}$ & $\mathrm{CID}-1$ & $51^{\mathrm{a}}$ & $72^{\mathrm{a}}$ & $48^{\mathrm{a}}$ & $41^{\mathrm{a}}$ & $56^{\mathrm{a}}$ & $60^{\mathrm{a}}$ & $33^{\mathrm{a}}$ & $44^{\mathrm{a}}$ \\
\cline { 2 - 12 } & $\mathrm{CID}-2$ & $39^{\mathrm{b}}$ & $61^{\mathrm{b}}$ & $46^{\mathrm{a}}$ & $46^{\mathrm{a}}$ & $41^{\mathrm{b}}$ & $45^{\mathrm{b}}$ & $32^{\mathrm{a}}$ & $40^{\mathrm{a}}$ \\
\hline
\end{tabular}

Note: $\quad \mathrm{T}, \mathrm{J}, \mathrm{H}$, and M refer to the tillering, jointing-booting, heading-flowering, and milky stages, respectively. Means followed by the same letter $(\mathrm{a}, \mathrm{b})$ do not differ significantly at the $5 \%$ level by $\mathrm{t}$ test. 
Table 5. Nitrogen and phosphorus losses through subsurface water leakage after five days flooding during the four growth stages in 2015 and 2016.

\begin{tabular}{|c|c|c|c|c|c|c|c|c|c|}
\hline \multirow{2}{*}{ Form of $\mathrm{N}$ and $\mathrm{P}$} & \multirow{2}{*}{ Treatments } & \multicolumn{4}{|c|}{2015} & \multicolumn{4}{|c|}{2016} \\
\hline & & $\mathrm{T}$ & $\mathrm{J}$ & $\mathrm{H}$ & M & $\mathrm{T}$ & $\mathrm{J}$ & $\mathrm{H}$ & M \\
\hline \multirow{3}{*}{$\begin{array}{c}\mathrm{NH}_{4}^{+}-\mathrm{N} \\
\left(\mathrm{g} \mathrm{ha}^{-1}\right)\end{array}$} & CID-1 & $185.6^{\mathrm{a}}$ & $80.8^{\mathrm{a}}$ & $135.0^{\mathrm{a}}$ & $72.6^{\mathrm{a}}$ & $74.2^{\mathrm{a}}$ & $103.2^{\mathrm{a}}$ & $86.7 \mathrm{a}$ & $45.4 \mathrm{a}$ \\
\hline & CID-2 & $179.2^{\mathrm{a}}$ & $88.8^{\mathrm{a}}$ & $146.6^{\mathrm{a}}$ & $71.2^{\mathrm{a}}$ & $83.4^{\mathrm{a}}$ & $92.6^{\mathrm{a}}$ & $87.8 \mathrm{a}$ & $50.8 \mathrm{a}$ \\
\hline & $\mathrm{CK}$ & $167.6^{\mathrm{a}}$ & $75.7^{\mathrm{a}}$ & $121.2^{\mathrm{a}}$ & $70.4^{\mathrm{a}}$ & $70.4^{\mathrm{a}}$ & $88.2^{\mathrm{a}}$ & $84.0^{\mathrm{a}}$ & $46.8^{\mathrm{a}}$ \\
\hline \multirow{3}{*}{$\begin{array}{l}\mathrm{NO}_{3}^{-}-\mathrm{N} \\
\left(\mathrm{g} \mathrm{ha}^{-1}\right)\end{array}$} & CID-1 & $208.8^{\mathrm{b}}$ & $118.1^{\mathrm{b}}$ & $77.6^{\mathrm{b}}$ & $56.8^{\mathrm{b}}$ & $264.0^{\mathrm{b}}$ & $236.4^{b}$ & $180.5^{\mathrm{b}}$ & $131.2^{\mathrm{b}}$ \\
\hline & CID-2 & $164.5^{\mathrm{c}}$ & $89.4^{c}$ & $74.4^{\mathrm{b}}$ & $51.6^{\mathrm{b}}$ & $185.2^{\mathrm{c}}$ & $152.6^{\mathrm{c}}$ & $141.9^{\mathrm{b}}$ & $146.3^{\mathrm{b}}$ \\
\hline & $\mathrm{CK}$ & $301.6^{\mathrm{a}}$ & $151.6^{\mathrm{a}}$ & $158.6^{\mathrm{a}}$ & $104.0^{\mathrm{a}}$ & $563.9^{\mathrm{a}}$ & $488.3^{\mathrm{a}}$ & $310.1^{\mathrm{a}}$ & $281.8^{\mathrm{a}}$ \\
\hline \multirow{3}{*}{$\begin{array}{c}\text { TP } \\
\left(\mathrm{g} \mathrm{ha}^{-1}\right)\end{array}$} & CID-1 & $4.42^{\mathrm{b}}$ & $4.30^{\mathrm{b}}$ & $3.23^{\mathrm{b}}$ & $3.40^{\mathrm{b}}$ & $4.94^{\mathrm{b}}$ & $3.88^{\mathrm{b}}$ & $3.99^{\mathrm{b}}$ & $3.18^{\mathrm{b}}$ \\
\hline & CID-2 & $3.96^{\mathrm{b}}$ & $3.65^{\mathrm{b}}$ & $3.25^{\mathrm{b}}$ & $3.37^{\mathrm{b}}$ & $4.32^{\mathrm{b}}$ & $3.12^{b}$ & $3.62^{b}$ & $3.09^{\mathrm{b}}$ \\
\hline & $\mathrm{CK}$ & $6.20^{\mathrm{a}}$ & $6.76^{\mathrm{a}}$ & $5.04^{\mathrm{a}}$ & $5.14^{\mathrm{a}}$ & $6.92^{\mathrm{a}}$ & $6.36^{\mathrm{a}}$ & $6.31^{\mathrm{a}}$ & $6.74^{\mathrm{a}}$ \\
\hline
\end{tabular}

Note: $\quad \mathrm{T}, \mathrm{J}, \mathrm{H}$, and $\mathrm{M}$ refer to the tillering, jointing-booting, heading-flowering, and milky stages, respectively. Means followed by the same letter $(a, b)$ do not differ significantly at the $5 \%$ level by t test.

for CID-2 and AWD reached peak at the first or third flooding day before dropping to a stable value, whereas that of $\mathrm{NO}_{3}^{-}-\mathrm{N}$ at the tillering stage and TP at the headingflowering and milky stages showed a slightly increased trend.

Table 5 shows $\mathrm{N}$ and $\mathrm{P}$ losses through subsurface water leakage after five days of flooding at four growth stages in two years. The losses of $\mathrm{NH}_{4}^{+}-\mathrm{N}$ from CID-1 and CID-2 treatments at four growth stages were increased on average by $8.0 \%$ and $9.8 \%, 11.9 \%$ and $10.3 \%, 7.3 \%$ and $12.7 \%$, and $2.3 \%$ and $7.3 \%$ for two years, respectively, whereas no significant differences were observed among them compared with the AWD treatments. The losses of $\mathrm{NO}_{3}^{-}-\mathrm{N}$ for CID-1 and CID-2 treatments during the four growth stages were significantly reduced on average by $35.6 \%$ and $49.3 \%, 44.3 \%$ and $56.3 \%, 33.7 \%$ and $48.9 \%$, and $49.9 \%$ and $49.7 \%$ for two years, respectively. However, significant differences in $\mathrm{NO}_{3}^{-}-\mathrm{N}$ losses were only observed at the tillering and jointing-booting stages. The losses of TP from CID-1 and CID-2 treatments at four growth stages on average for two years were significantly reduced by $28.7 \%$ and $37.0 \%, 37.6 \%$ and $48.4 \%, 36.3 \%$ and $39.0 \%$, and $43.4 \%$ and $44.2 \%$, respectively, compared to the AWD. No significant difference for the losses of TP was discovered between CID-1 and CID-2 treatments at four growth stages in two years.

\section{Discussion}

In South China, paddy-growing season coincides with the rainy season. For AWD management, rainfall use efficiency is not very favorable due to the low storage ability of rainfall. Meanwhile, high nutrient losses may be found in drainage water through the root zone, as a result of intense rainfall, regardless of organic or mineral [23]. Controlled irrigation and drainage (CID) can retain higher water depths after concentrated rainfall or extreme rainstorms and keep lower drainage, which leads to periods of alternating drought and flooding during rice growth. Researches on water use and $\mathrm{N}$ and $\mathrm{P}$ losses under CID are important for improving the ability of water savings and reducing non-point source pollution.

\section{Effect on Water Use}

Research on AWD confirmed that high watersaving potential does exist [24-25]. However, rainwater harvesting, storage, and use for AWD were significantly lower than CID due to the lower-field water depth [26]. Similar observations were made in the present study, and CID treatment improved the effective irrigation volumes and reduced irrigation frequencies over AWD, which means that efficient use of rainwater is improved and drainage pressure of paddy fields is reduced. Water use efficiency for paddy fields is mainly determined by the ratio of evapotranspiration-to-grain yield. Research has demonstrated that long depths of standing water in paddy fields would lead to high water evaporation [27], which was similar with our conclusion that ET under CID treatments was higher than AWD - especially for the CID-1 treatment. Meanwhile, CID treatment with severe soil drying and long periods of flooding led to heavier yield losses than AWD treatment, which might be explained by various anatomical changes in plants [28]. Therefore, WUE under CID was lower than AWD, which is not economic for farmers even if with improved available irrigation, rainwater harvesting, and reduced irrigation frequencies.

\section{Effect on the N and P Losses in Surface Water}

Many studies have suggested that $\mathrm{N}$ and $\mathrm{P}$ losses in drainage water are closely related to water management. 
Yoshinaga et al. showed that less irrigation water with a low percolation flux in paddy fields can keep runoff $\mathrm{N}$ low [29]. Lu et al. reported that $\mathrm{N}$ concentrations in surface water and $\mathrm{N}$ runoff losses decline with the persistence of a flooding condition, which was overall consistent with the founding of CID in our study [15]. However, as we have found, $\mathrm{NH}_{4}^{+}-\mathrm{N}$ concentrations under $\mathrm{CID}$ at tillering and milky stages slightly increased at the end of flooding, which might be caused by the lower absorbing ability of plants at that period and the limited nitrification process. When paddy soil remained a drought environment for a period of time, the aboveground biomass and $\mathrm{N}$ accumulation were significantly higher than that experienced in a period of flooding time [30]. As a consequence, $\mathrm{N}$ and $\mathrm{P}$ concentrations at the flooding day for CID-1 were higher than CID-2. This phenomenon also explains that the possible losses of $\mathrm{NH}_{4}^{+}-\mathrm{N}$ and $\mathrm{NO}_{3}^{-}-\mathrm{N}$ for CID-1 at the fifth flooding day were higher than CID-2 treatment. Similarly, Gao et al. had reported that the mean concentrations of $\mathrm{NH}_{4}^{+}-\mathrm{N}, \mathrm{NO}_{3}^{-}-\mathrm{N}$, and TP in FDTF (first drought then flooding) for the single growth stage of paddy were significantly higher than in FFTD (first flooding then drought) [22]. Therefore, the drought period followed by irrigation or rainfall increased the risk of $\mathrm{N}$ and $\mathrm{P}$ losses. Optimum drainage time should be selected according to the changes in $\mathrm{N}$ and $\mathrm{P}$ concentrations. However, previous studies found that $\mathrm{NH}_{4}^{+}-\mathrm{N}$ and TP concentrations mainly corresponded with fertilizer application, whereas that of $\mathrm{NO}_{3}^{-}-\mathrm{N}$ was mostly attributed to water depth change [31-32]. The alternate drought and flooding process can form a protective film on the soil surface, which causes the disturbance by irrigation or rainfall at the next growth stage to be lower than the previous stages [8]. Thus, in our experiments CID-2 can significantly reduce the possible losses of $\mathrm{NH}_{4}^{+}-\mathrm{N}$ and $\mathrm{TP}$ at the fertilizer application period and significantly cut down possible losses of $\mathrm{NO}_{3}^{-}-\mathrm{N}$ at the former three growth stages compared with CID-1. Meanwhile, the discrepancy of $\mathrm{N}$ and $\mathrm{P}$ concentrations at the first flooding day between CID-1 and CID-2 gradually decreased at four growth stages.

\section{Effects on $\mathrm{N}$ and P Losses in Subsurface Water}

Soil cracks formed in paddy fields under drought stress may be the main routes of preferential flow, which can improve the velocity and volume of $\mathrm{N}$ and $\mathrm{P}$ transport to the subsoil and the groundwater [33-34]. As a result, CID-1 treatment enhanced $\mathrm{N}$ and $\mathrm{P}$ concentrations at the first re-flooding day and improved the risk of leaching losses. Alternating wetting and drying changes the anaerobic environment caused by continuous flooding and accelerates the nitrification process, which improved the consumption of $\mathrm{NH}_{4}^{+}-\mathrm{N}$ and expedite $\mathrm{NO}_{3}^{-}-\mathrm{N}$ loading to the groundwater [10]. On the other hand, the retardation factor and dynamic adsorption capacity for $\mathrm{NO}_{3}{ }^{-}$are lower than those for $\mathrm{NH}_{4}^{+}$ions, and the migration velocity of $\mathrm{NH}_{4}^{+}$in the subsoil is very small [35]. Thus the average $\mathrm{NH}_{4}^{+}-\mathrm{N}$ concentrations from CID and AWD treatments at four growth stages for two years are kept on lower and stable values than $\mathrm{NO}_{3}^{-}-\mathrm{N}$ concentrations, and the leaching losses of $\mathrm{NH}_{4}^{+}-\mathrm{N}$ were not significantly different in AWD and CID. Furthermore, in the present study CID can significantly reduce the leaching losses of $\mathrm{NO}_{3}{ }^{-}-\mathrm{N}$ compared with $\mathrm{AWD}$, which was also confirmed by Katsura et al. that the losses of $\mathrm{NO}_{3}^{-}-\mathrm{N}$ in percolation water under AWD were significantly higher than a period of flooding treatment [30]. Moreover, CID-2 treatment significantly reduced the leaching losses of $\mathrm{NO}_{3}^{-}-\mathrm{N}$ compared to CID-1 at the former two stages, whereas no significant difference was found at other stages. This is because the drought period before irrigation can accumulate $\mathrm{NO}_{3}^{-}-\mathrm{N}$ and easily transport $\mathrm{NO}_{3}^{-}-\mathrm{N}$ to the subsoil after irrigation, especially for the former growth stages that corresponded to the possible losses of $\mathrm{NO}_{3}^{-}-\mathrm{N}$ in surface water. Flooding conditions created anaerobic conditions with the reduction of $\mathrm{Fe}^{3+}$ to $\mathrm{Fe}^{2+}$, which increased the release of $\mathrm{P}$ into the soil solution. Tang et al. mentioned that the threshold value of eutrophication induced by $\mathrm{P}$ in paddy fields of water was $0.05 \mathrm{mg} / \mathrm{L}$ [36]. Xiao et al. had demonstrated that $\mathrm{P}$ leaching can take place and may give rise to eutrophication, particularly in the latter day of flooding [19], which was consistence with our research. However, fluctuations in TP concentration under CID and AWD treatments were not obvious, which may due to the stronger adsorption ability of soil, which limited the migration of $\mathrm{P}$ [37]. In addition, compared to AWD, CID treatment can significantly reduce the leaching losses of TP, whereas no significant difference was found between CID-1 and CID-2. Higher irrigation for CID played a dilution effect in the subsurface water compared to AWD, and no distinction for subsurface water leakage among them was observed.

\section{Conclusions}

Although the effective irrigation quantities for CID-1 and CID-2 were 1.54 and 1.40 times higher in 2015 and 1.30 and 1.13 times higher in 2016, respectively, water use efficiency significantly decrease compared with AWD. During four growth stages of water control, $\mathrm{N}$ and $\mathrm{P}$ concentrations in surface water at the first flooding day for CID-1 were higher than CID-2, while the discrepancy gradually decreased. Moreover, the possible losses of $\mathrm{NH}_{4}^{+}$-N and TP for CID-1 on the fifth day of flooding were significantly higher than for CID-2 during the fertilizer application period, whereas significant differences for $\mathrm{NO}_{3}^{-}-\mathrm{N}$ losses were observed at the former three growth stages. Fluctuation ranges of $\mathrm{NH}_{4}^{+}-\mathrm{N}, \mathrm{NO}_{3}^{-} \mathrm{N}$, and TP concentrations were lower in subsurface water. Compared to AWD, CID treatments can significantly reduce the leaching losses of $\mathrm{NO}_{3}^{-}-\mathrm{N}$ and $\mathrm{TP}$, whereas no significant difference for the leaching losses of $\mathrm{NH}_{4}^{+}-\mathrm{N}$ were observed. CID-1 significantly increased the leaching losses of $\mathrm{NO}_{3}{ }^{-} \mathrm{N}$ at the former two stages over CID-2, but no significant difference was found at the leaching losses of $\mathrm{NH}_{4}^{+}-\mathrm{N}$ and TP. Under CID, the main losses of $\mathrm{N}$ in surface water were derived from $\mathrm{NH}_{4}^{+}-\mathrm{N}$, whereas in 
subsurface water, $\mathrm{NO}_{3}{ }^{-}-\mathrm{N}$ was the main loss form of $\mathrm{N}$. Therefore, the present study has provided a platform for farmers to choose optimum drainage time and reasonable drainage method.

\section{Acknowledgements}

This work was funded by the Key Program granted by the National Nature and Science Foundation of China (Nos. 51479063, 41401628, and 51679108) and supported by the Fundamental Research Funds for the Central University (grant No. 2016B42114). The authors extend their gratitude to the editor and the anonymous reviewers for substantial comments on earlier versions of this paper.

\section{References}

1. FAOSTAT. Food Agricultural Organization, UN, 2011. Available online: http://faostat.fao.org/. (accessed on 10, 04, 2017.)

2. LI H.M., LI M.X. Sub-group formation and the adoption of the alternate wetting and drying irrigation method for rice in China. Agricultural Water Management. 97 (5), 700, 2010.

3. ZHANG W.J., LI G.H., YANG Y.M., LI Q., ZHANG J., LIU J.Y., WANG S.H., TANG S., DING Y.F. Effects of nitrogen application rate and ratio on lodging resistance of super rice with different genotypes. Journal of Integrative Agriculture. 13 (1), 63, 2014.

4. JU X.T., XING G.X., CHEN X.P., ZHANG S.L., ZHANG L.J., LIU X.J., CUI Z.L., YIN B., CHRISTIE P., ZHU Z.L., ZHANG F.S. Reducing environmental risk by improving $\mathrm{N}$ management in intensive Chinese agricultural systems. Proceedings of the National Academy of Sciences. 106, 3041, 2009.

5. QIAN J., ZHANG L.P., WANG W.Y., LIU Q. Effects of vegetation cover and slope length on nitrogen and phosphorus loss from a sloping land under simulated rainfall. Polish Journal of Environment Studies. 23 (3), 835, 2014.

6. CHIRINDA N., CARTER M.S., ALBERT K.R., AMBUS P., OLESEN J.E., PORTER J.R., PETERSEN S.O. Emissions of nitrous oxide from arable organic and conventional cropping systems on two soil types. Agriculture, Ecosystems and Environment. 136 (3-4), 199, 2010.

7. LAMPAYAN R.M., REJESUS R.M., SINGLETON G.R., BOUMAN B.A.M. Adoption and economics of alternate wetting and drying water management for irrigated lowland rice. Field Crops Research. 170 ,95, 2015.

8. LAMPAYAN R.M., SAMOY-PASCUAL K.C., SIBAYAN E.B., ELLA V.B., JAYAG O.P., CABANGON R.J., BOUMAN B.A.M. Effects of alternate wetting and drying (AWD) threshold level and plant seedling age on crop performance, water input, and water productivity of transplanted rice in Central Luzon, Philippines. Paddy and Water Environment. 13 (3), 215, 2015.

9. PENG S.Z., YANG S.H., XU J.Z., LUO Y.F., HOU H.J. Nitrogen and phosphorus leaching losses from paddy fields with different water and nitrogen managements. Paddy and Water Environment. 9 (3), 333, 2011.

10. TAN X.Z., SHAO D.G., LIU H.H., YANG F.S., XIAO C., YANG H.D. Effects of alternate wetting and drying irrigation on percolation and nitrogen leaching in paddy fields. Paddy and Water Environment. 11 (1), 381, 2013.

11. WESSTR M I., JOEL A., MESSING I. Controlled drainage and subirrigation - A water management option to reduce non-point source pollution from agricultural land. Agriculture, Ecosystems and Environment. 198, 74, 2014.

12. BONAITI G., BORIN M. Efficiency of controlled drainage and subirrigation in reducing nitrogen losses from agricultural fields. Agricultural Water Management. 98 (2), 343, 2010.

13. MATSUO N., TAKAHASHI M., NAKANO H., FUKAMI K., TSUCHIYA S., MORITA S., KITAGAWA H., NAKANO K., NAKAMOTO H., TASAKA K. Growth and yield responses of two soybean cultivars grown under controlled groundwater level in Southwestern Japan. Plant Production Science. 16 (1), 84, 2013.

14. NG H.Y.F., TAN C.S., DRURY C.F., GAYNOR J.D. Controlled drainage and subirrigation influences tile nitrate loss and corn yields in a sandy loam soil in Southwestern Ontario. Agriculture, Ecosystems and Environment. 90 (1), 81, 2002.

15. LU B., SHAO G.C., YU S.E., WU S.Q., XIE X.H. The effects of controlled drainage on $\mathrm{N}$ concentration and loss in paddy field. Journal of Chemistry. 1, 2016.

16. SHAO G.C., WANG M.H., YU S.E., LIU N., XIAO M.H., YUAN M. Potential of controlled irrigation and drainage for reducing nitrogen emission from rice paddies in Southern China. Journal of Chemistry. 1, 2016.

17. PENG S.Z., HE Y.P., YANG S.H., XU J.Z. Effect of controlled irrigation and drainage on nitrogen leaching losses from paddy fields. Paddy and Water Environment. 13 (4), 303, 2015.

18. PENG S.Z., AI L.K., HE Y.P., ZHANG J.G., YANG S.H. Effect of irrigation and drainage coupling management on rice water requirement. Journal of Hydraulic Engineering. 45 (3), 20, 2014.

19. XIAO M.H., YU S.E., SHAO G.C., SHE D.L. Technical standards of irrigation and drainage management in paddy field of water-saving and pollution reduction with high yield. WFL Publisher Science and Technology. 10 (2), 1005, 2012.

20. GHEYSARI M., MIRLATIFI S.M., HOMAEE M., ASADI M.E., HOOGENBOOM G. Nitrate leaching in a silage maize field under different irrigation and nitrogen fertilizer rates. Agricultural Water Management. 96 (6), 946, 2009.

21. DICKIN E., WRIGHT D. The effects of winter waterlogging and summer drought on the growth and yield of winter wheat (Triticum aestivum L.). European Journal of Agronomy. 28 (3), 234, 2008.

22. GAO S.K., YU S.E., SHAO G.C., SHE D.L., WANG M., GUO R., CAO R.Z., YAN S.F., DING J.H. Effects of controlled irrigation and drainage on nitrogen and phosphorus concentrations in paddy water. Journal of Chemistry. 1, 2016.

23. KURTZMAN D., SHAPIRA R.H., BAR-TAL A., FINE P., RUSSO D. Nitrate fluxes to groundwater under citrus orchards in a mediterranean climate: observations, calibrated models, simulations and agro-hydrological conclusions. Journal of Contaminant Hydrology. 151, 93, 2013.

24. YAO F.X., HUANG J.L., CUI K.H., NIE L.X., XIANG J., LIU X.J., WU W., CHEN M.X., PENG S.B. Agronomic performance of high-yielding rice variety grown under alternate wetting and drying irrigation. Field Crops Research. 126, 16, 2012. 
25. YE Y.S., LIANG X.Q., CHEN Y.X., LIU J., GU J., GUO R., LI L. Alternate wetting and drying irrigation and controlledrelease nitrogen fertilizer in late-season rice. Effects on dry matter accumulation, yield, water and nitrogen use. Field Crops Research. 144, 212, 2013.

26. SHAO G.C., DENG S., LIU N., YU S.E., WANG M.H., SHE D.L. Effects of controlled irrigation and drainage on growth, grain yield and water use in paddy rice. European Journal of Agronomy. 53, 1, 2014.

27. LU W.X., CHENG W.G., ZHANG Z., XIN X., WANG X.H. Differences in rice water consumption and yield under four irrigation schedules in central Jilin Province, China. Paddy and Water Environment. 14 (4), 473, 2016.

28. MAHESWARI J.M.N., MARTIN G.J. Relatively simple irrigation scheduling and $\mathrm{N}$ application enhances the productivity of aerobic rice (Oryza sativaL.). American Journal of Plant Physiology. 2 (4), 261, 2007.

29. YOSHINAGA I., MIURA A., HITOMI T., HAMADA K., SHIRATANI E. Runoff nitrogen from a large sized paddy field during a crop period. Agricultural Water Management. 87 (2), 2007.

30. KATSURA K., OKAMI M., MIZUNUMA H., KATO Y. Radiation use efficiency, $\mathrm{N}$ accumulation and biomass production of high-yielding rice in aerobic culture. Field Crops Research. 117 (1), 81, 2010.

31. YANG S.H., PENG S.Z., XU J.Z., HE Y.P., WANG Y.J. Effects of water saving irrigation and controlled release nitrogen fertilizer managements on nitrogen losses from paddy fields. Paddy and Water Environment. 13 (1), 71, 2015.

32. WANG J., WANG D., ZHANG G., WANG Y., WANG C., TENG Y., CHRISTIE P. Nitrogen and phosphorus leaching losses from intensively managed paddy fields with straw retention. Agricultural Water Management. 141, 66, 2014.

33. ZHANG Z.B., ZHOU H., ZHAO Q.G., LIN H., PENG $X$. Characteristics of cracks in two paddy soils and their impacts on preferential flow. Geoderma. 228-229, 114, 2014.

34. CHENG J.H., ZHANG H.J., ZHANG Y.Y., CHEN Y.Z., YAN W.B. Characteristics of preferential flow paths and their impact on nitrate nitrogen transport on agricultural land. Polish Journal of Environment Studies. 23 (6), 1959, 2014.

35. FRONCZYK J., SIECZKA A., LECH M., RADZIEMSKA M., LECHOWICZ Z. Transport of nitrogen compounds through subsoils in agricultural areas: column tests. Polish Journal of Environmental Studies. 25 (4), 2016.

36. TANG J.L., WANG T., ZHU B., ZHAO P., XIAO Y., WANG R. Tempo-spatial analysis of water quality in tributary bays of the Three Gorges Reservoir region (China). Environmental Science and Pollution Research. 22 (21), 16709, 2015.

37. XIE X.J., RAN W., SHEN Q.R., YANG C.Y., YANG J.J., CAO Z.H. Field studies on 32P movement and P leaching from flooded paddy soils in the region of taihu lake, China. Environmental Geochemistry and Health. 26 (2), 237, 2004. 